\title{
Recent advances in managing hepatitis B
}

\author{
Brian J McMahon
}

Address: Liver Disease and Hepatitis Program, Alaska Native Tribal Health Consortium, 4315 Diplomacy Drive, Anchorage, AK 99508, USA

Email: bdm9@cdc.gov

Fl000 Medicine Reports 2010, 2:II (doi:I0.3410/M2-II)

The electronic version of this article is the complete one and can be found at: http://fl000.com/reports/medicine/content/2/I I

\begin{abstract}
In the past two years, several national and international bodies have made recommendations and published updated practice guidelines for hepatitis B. In addition, new drugs have become available for treatment of hepatitis $B$. This article will review the new recommendations for screening for hepatitis $B$ and for first-line antiviral medications to use for treatment. In addition, I will discuss the recent recommendations on treating hepatitis $B$ and human immunodeficiency virus co-infection and the screening of people receiving immunosuppressive therapy.
\end{abstract}

\section{Introduction and context}

In the past two years, several important events have focused attention on chronic hepatitis B virus (HBV) infection in the US and elsewhere (Table 1). Three new evidenced-based practice guidelines sponsored by regional liver societies have helped clarify HBV treatment [1-3]. In addition, the Centers for Disease Control and Prevention (CDC) recently published a recommendation for the detection and management of chronic HBV [4], and the National Institutes of Health held the first Consensus Conference on Chronic HBV [5]. Also, a treatment algorithm by American hepatologists and a consensus of experts in Canada on treatment of hepatitis $\mathrm{B}$, both of which were funded by pharmaceutical companies, were recently published [6,7]. Finally, the Institute of Medicine has published a set of comprehensive recommendations on HBV and HCV (hepatitis C virus) in the US [8]. In the past 5 years, five new drugs for treatment of HBV have been licensed in the US [1,9-13]. The following article will highlight the most important points, from a clinician standpoint, that have come out of these guidelines and conferences.

\section{Recent advances}

First of all, persons with chronic HBV cannot be managed unless they have been identified. The vast majority of chronically infected persons were born in countries with a prevalence of hepatitis B surface antigen
(HBsAg) above 2\% and include anyone born in Asia, Africa, the South Pacific Islands, Eastern and Southern Europe, and indigenous populations of Australia, New Zealand, and the Arctic and parts of the Caribbean and South America [4]. The CDC recommends that all persons born in these regions be screened for HBsAg and anti-HBs and that those found to be negative be given hepatitis $\mathrm{B}$ vaccine. Other high-risk populations are also outlined in the CDC report [4]. Currently, in the US, most persons with chronic HBV are unidentified [4]. A study has shown that up to $65 \%$ of those newly found by serosurveys to have HBV were unaware of their infection status [14]. Another study has shown that less than half of persons of Chinese descent in the US have been tested for HBV [15].

Studies on the natural history of HBV in the past few years have identified important risk factors for the development of hepatocellular carcinoma (HCC) and cirrhosis $[16,17]$. The REVEAL study from Taiwan, a population-based study following over $3000 \mathrm{HBsAg}$ positive persons for 11 years, found that in persons over the age of 40, HBV DNA levels that are above $10^{5}$ copies/ $\mathrm{mL}(20,000 \mathrm{IU} / \mathrm{mL})$ at the beginning or end of an 11-year prospective follow-up are a significant risk factor for both HCC and cirrhosis regardless of the ALT (alanine aminotransferase) level $[18,19]$. This same study showed that genotype $\mathrm{C}$ and basal core promoter 
mutation were additional risk factors in those with HBV DNA levels above $10^{4}$ to $10^{5}$ copies/mL and that in persons over 40 years of age with all three risk factors, the risk of HCC was 2\% per year [20].

Updated evidenced-based guidelines for the management of chronic HBV recommend that those persons with moderate or severe liver necroinflammation or fibrosis (which is often associated with elevated serum liver enzyme levels) be treated for HBV [1-3]. For further details, see the American Association for the Study of Liver Diseases (AASLD) Practice Guideline on Chronic Hepatitis B: 2009 Update or one of the other liver society HBV practice guidelines listed in Table 1. Table 2 lists the first- and second-line antiviral medications recommended by all liver societies. The greatest detriment to treating $\mathrm{HBV}$ is the development of antiviral resistance. The consensus of guidelines is that the goal of treatment should be complete suppression of HBV DNA to a level undetectable by a polymerase chain reaction-based assay. The alfa interferons have the advantage that resistance does not develop to them and there is a limit to the duration of treatment of not more than 1 year, but only about $30 \%$ of patients respond to them $[1,10]$. Entecavir and tenofovir are potent nucleoside/tide analogues that render most patients negative for $\mathrm{HBV}$ DNA. These two drugs have a high barrier to resistance and require more than one $\mathrm{HBV}$ mutation for resistance to occur, so they are currently considered first-line drugs. In contrast, lamivudine, telbivudine, and emtricitabine require only one HBV mutation to occur for resistance to develop and thus have a low barrier for resistance. The rate of resistance occurrence between these three antivirals is related to the potency of the drug, with telbivudine being the most potent and lamivudine the least. Adefovir is structurally related to tenofovir, is less potent at the dosage licensed, and has a higher rate of nephrotoxicity. Also, approximately 30\% of persons have a suboptimal response to adefovir $[1,11]$.

For some time, the AASLD practice guideline for HCC has recommended that persons with a family history of HCC, those with cirrhosis, and males over 40 and
Table 2. Preferred antiviral medications for the treatment of chronic hepatitis B

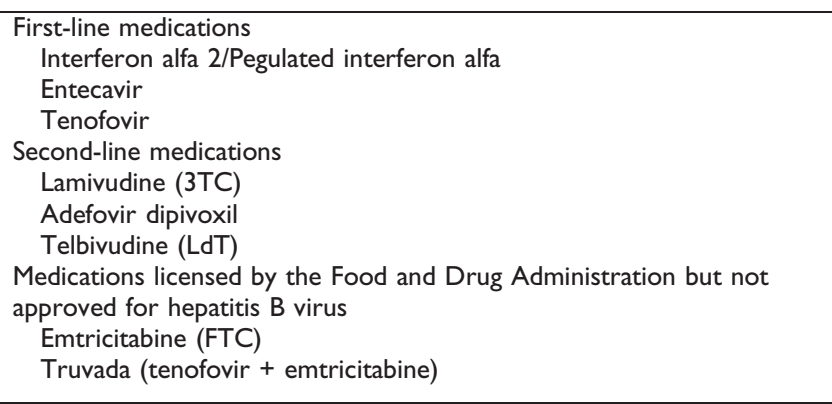

females over 50 with chronic HBV infection undergo 6-month surveillance for HCC to detect this cancer early. The guideline recommends liver ultrasound as the primary screening modality, but many clinicians include alpha-fetoprotein testing as well [21].

Two other issues about treatment are worth mentioning. First, HBV/HIV co-infection is not uncommon. A highly active retroviral therapy (HAART) regimen that included lamivudine as the only active drug against HBV may adequately suppress HIV, but resistance to HBV will likely develop in up to $90 \%$ of patients in 3-5 years [22]. Several studies have shown an increased rate of $\mathrm{HBV}$ liver-related death in co-infected patients in whom both viruses are not adequately suppressed [23]. A second important issue is that, in the past decade, it has become clear that reactivation of $\mathrm{HBV}$ with flares of hepatitis, even fulminate leading to death, has occurred in patients with chronic HBV infection who were administered chemotherapy or other immunosuppressive drugs, including tissue necrosis factor blockers. HBV reactivation was even reported in inactive HBsAg-positive 'healthy' carriers who had normal liver function tests and who were negative for HBV DNA [24]. Controlled trials and comparison studies have clearly shown that the rate of exacerbation and flares of $\mathrm{HBV}$ can be reduced from $50 \%$ in untreated persons to $10 \%$ if an antiviral medication is given as prophylaxes started at the beginning of chemotherapy and continued for 6 months after completion [25].

Table I. Recent Consensus Conferences and liver society guidelines on chronic hepatitis B

\begin{tabular}{|c|c|c|}
\hline Conference/Guideline & Year held/ published & Download website report free \\
\hline AASLD Chronic HBV 2009 Update & 2009 & http://www3.interscience.wiley.com/cgi-bin/fulltext/I 22523089/PDFSTART [I] \\
\hline EASL HBV Guideline 2009 Update & 2009 & http://www.easl.eu/assets/application/files/f6fe I 3 I 29b5f0df_file.pdf [3] \\
\hline APASL HBV Guideline 2008 Update & 2008 & http://www.springerlink.com/content/du475u l 2q655 I75j/fulltext.pdf [2] \\
\hline NIH Consensus Conference HBV & 2008 & http://consensus.nih.gov/2008/2008HepatitisBCDCl20main.htm [26] \\
\hline Recommendations Chronic HBV & 2008 & http://www.cdc.gov/mmWR/PDF/rr/rr5708.pdf [27] \\
\hline IOM Report on HBV/HCV & 2010 & http://www.nap.edu/catalog.php?record_id= I $2793[8]$ \\
\hline
\end{tabular}

AASLD, American Association for the Study of Liver Diseases; APASL, Asian Pacific Association for the Study of the Liver; EASL, European Association for the Study of the Liver; HBV, hepatitis B virus; HCV, hepatitis C virus; IOM, Institute of Medicine; NIH, National Institutes of Health. 


\section{Implications for clinical practice}

The most important points for clinical practice are the following:

1. Providers need to remember to screen their high-risk patients for HBsAg and anti-HBs to identify persons with chronic HBV who need management and to vaccinate those who are negative with hepatitis $B$ vaccine.

2. It is important for clinicians treating HBV to minimize the risk of developing resistance while maximizing the probability that patients will have an excellent response to the antiviral medication chosen. Therefore, clinicians should choose one of the first-line drugs listed in Table 2. While there are advantages and disadvantages to all of the first-line drugs such as cost, toxicity, and convenience, it is difficult to recommend one drug over the other and the decision of which first-line drug to use should be left up to the physician and patient to decide.

3. High-risk HBV chronically infected persons should undergo regular surveillance for HCC, as recommended by AASLD practice guidelines.

4. If a clinician is treating HIV alone, they should use a HAART combination of drugs that do not target HBV or, if treating both infections, use a HAART regimen that has at least two antivirals active against both viruses, either tenofovir plus lamivudine or emtricitabine (Truvada ${ }^{\circledR}$; Gilead Sciences, Inc., Foster City, CA, USA).

5. Before persons undergo chemotherapy or immunosuppressive therapy, they should be screened for HBV if they belong to one of the high-risk groups. If found to be HBsAg-positive, they should be administered antiviral therapy from the time of initiation of chemotherapy or immunosuppressive therapy until at least 6 months after completion.

\section{Abbreviations}

AASLD, American Association for the Study of Liver Diseases; CDC, Centers for Disease Control and Prevention; HAART, highly active retroviral therapy; HBsAg, hepatitis B surface antigen; HBV, hepatitis B virus; HCC, hepatocellular carcinoma.

\section{Competing interests}

The author declares that he has no competing interests.

\section{References}

I. Lok AS, McMahon BJ: Chronic hepatitis B: update 2009. Hepatology 2009, 50:66I-2.
2. Liaw YF, Leung N, Kao JH, Piratvisuth T, Gane E, Han KH, Guan R, Lau GK, Locarnini S; for the Chronic Hepatitis B Guideline Working Party of the Asian-Pacific Association for the Study of the Liver: Asian-Pacific consensus statement on the management of chronic hepatitis B: a 2008 update. Hepatol Int 2008, 2:263-83.

3. European Association for the Study of the Liver: [EASL clinical practice guidelines. Management of chronic hepatitis B]. Gastroenterol Clin Biol 2009, 33:539-54.

4. Weinbaum CM, Mast EE, Ward JW: Recommendations for identification and public health management of persons with chronic hepatitis B virus infection. Hepatology 2009, 49: S35-S44.

5. Sorrell MF, Belongia EA, Costa J, Gareen IF, Grem JL, Inadomi JM, Kern ER, McHugh JA, Petersen GM, Rein MF, Strader DB, Trotter HT: National Institutes of Health consensus development conference statement: management of hepatitis B. Hepatology 2009, 49:S4-SI2.

6. Keeffe EB, Dieterich DT, Han SH, Jacobson IM, Martin P, Schiff ER, Tobias H: A treatment algorithm for the management of chronic hepatitis B virus infection in the United States: 2008 update. Clin Gastroenterol Hepatol 2008, 6:|3|5-4I.

7. Sherman M, Shafran S, Burak K, Doucette K, Wong W, Girgrah N, Yoshida E, Renner E, Wong P, Deschênes M: Management of chronic hepatitis B: consensus guidelines. Can J Gastroenterol 2007, 2 I (Suppl C):5C-34C.

8. Institute of Medicine of the National Academies: Hepatitis and Liver Cancer: A National Strategy for Prevention and Control of Hepatitis B and C. Washington, DC: The National Academies Press; 2010.

9. Marcellin P, Heathcote EJ, Buti M, Gane E, de Man RA, Krastev Z, Germanidis G, Lee SS, Flisiak R, Kaita K, Manns M, Kotzev I, Tchernev K, Buggisch P, Weilert F, Kurdas OO, Shiffman ML, Trinh H, Washington MK, Sorbel J, Anderson J, Snow-Lampart A, Mondou E, Quinn J, Rousseau F: Tenofovir disoproxil fumarate versus adefovir dipivoxil for chronic hepatitis B. N Engl J Med 2008, 359:2442-55

10. Marcellin P, Lau GK, Bonino F, Farci P, Hadziyannis S, Jin R, Lu ZM, Piratvisuth T, Germanidis G, Yurdaydin C, Diago M, Gurel S, Lai MY, Button P, Pluck N; Peginterferon Alfa-2a HBeAg-Negative Chronic Hepatitis B Study Group: Peginterferon alfa-2a alone, lamivudine alone, and the two in combination in patients with HBeAg-negative chronic hepatitis B. N Engl J Med 2004, 35 I: I206- I7.

II. Marcellin P, Chang TT, Lim SG, Tong MJ, Sievert W, Shiffman ML, Jeffers L, Goodman Z, Wulfsohn MS, Xiong S, Fry J, Brosgart CL; Adefovir Dipivoxil 437 Study Group: Adefovir dipivoxil for the treatment of hepatitis B e antigen-positive chronic hepatitis B. N Engl J Med 2003, 348:808-16.

12. Lai CL, Gane E, Liaw YF, Thongsawat S, Wang Y, Chen Y, Heathcote EJ, Rasenack J, Bzowej N, Naoumov N, Chao G, Fielman Constance B, Brown NA: Telbivudine (LDT) vs. lamivudine for chronic hepatitis $B$ : first-year results from the international phase III globe trial. Hepatology 2005, 42(Suppl I):748A Abstract LBI.

13. Lai CL, Shouval D, Lok AS, Chang TT, Cheinquer H, Goodman Z, DeHertogh D, Wilber R, Zink RC, Cross A, Colonno R, Fernandes L; BEHoLD Al463027 Study Group: Entecavir versus lamivudine for patients with HBeAg-negative chronic hepatitis B. N Engl J Med 2006, 354:1011-20.

14. Lin SY, Chang ET, So SK: Why we should routinely screen Asian American adults for hepatitis B: a cross-sectional study of Asians in California. Hepatology 2007, 46:I034-I40.

I5. Hislop TG, Teh C, Low A, Li L, Tu SP, Yasui Y, Taylor VM: Hepatitis $B$ knowledge, testing and vaccination levels in Chinese immigrants to British Columbia, Canada. Can J Public Health 2007, 98:125-9.

16. McMahon BJ: The natural history of chronic hepatitis B virus infection. Hepatology 2009, 49:S45-S55.

17. McMahon BJ: The influence of hepatitis B virus genotype and subgenotype on the natural history of chronic hepatitis $B$. Hepatol Int 2009, 3:334-42. 
18. Chen CJ, Yang HI, Su J, Jen CL, You SL, Lu SN, Huang GT, lloeje UH; REVEAL-HBV Study Group: Risk of hepatocellular carcinoma across a biological gradient of serum hepatitis B virus DNA level. JAMA 2006, 295:65-73.

FI000 Factor 8.0 Exceptional

Evaluated by Stefano Bellentani I 5 Feb 2006, Kenrad Nelson 30 May 2006

19. Iloeje UH, Yang HI, Su J, Jen CL, You SL, Chen CJ: Predicting cirrhosis risk based on the level of circulating hepatitis B viral load. Gastroenterology 2006, 130:678-86.

20. Yang HI, Yeh SH, Chen PJ, lloeje UH, Jen CL, Su J, Wang LY, Lu SN, You SL, Chen DS, Liaw YF, Chen CJ; REVEAL-HBV Study Group: Associations between hepatitis $B$ virus genotype and mutants and the risk of hepatocellular carcinoma. J Natl Cancer Inst 2008, 100: I I34-43.

FI000 Factor 3.0 Recommended

Evaluated by Ellen Chang 27 Aug 2008

21. Bruix J, Sherman M: Management of hepatocellular carcinoma. Hepatology 2005, 42:1208-36.

22. Benhamou $Y$, Bochet M, Thibault V, Di Martino V, Caumes E, Bricaire F, Opolon P, Katlama C, Poynard T: Long-term incidence of hepatitis B virus resistance to lamivudine in human immunodeficiency virus-infected patients. Hepatology 1999 , 30:1302-6.

23. Thio CL, Seaberg EC, Skolasky R Jr, Phair J, Visscher B, Muñoz A, Thomas DL; Multicenter AIDS Cohort Study: HIV-I, hepatitis B virus, and risk of liver-related mortality in the Multicenter Cohort Study (MACS). Lancet 2002, 360:1921-6.

24. Yeo W, Johnson PJ: Diagnosis, prevention and management of hepatitis B virus reactivation during anticancer therapy. Hepatology 2006, 43:209-20.

25. Loomba R, Rowley A, Wesley R, Liang TJ, Hoofnagle JH, Pucino F, Csako G: Systematic review: the effect of preventive lamivudine on hepatitis $\mathbf{B}$ reactivation during chemotherapy. Ann Intern Med 2008, 148:5 19-28.

26. Belongia EA, Costa J, Gareen IF, Grem JL, Inadomi JM, Kern ER, McHugh JA, Petersen GM, Rein MF, Sorrell MF, Strader DB, Trotter HT: National Institutes of Health Consensus Development Conference Statement: management of hepatitis B. Ann Intern Med 2009, I50:104-10.

27. Weinbaum CM, Williams I, Mast EE, Wang SA, Finelli L, Wasley A, Neitzel SM, Ward JW; Centers for Disease Control and Prevention (CDC): Recommendations for identification and public health management of persons with chronic hepatitis B virus infection. MMWR Recomm Rep 2008, 57:1-20. 